\title{
Differentiation of newly described Antarctic bacterial isolates related to Roseobacter species based on 16S-235 rDNA internal transcribed spacer sequences
}

\author{
Rainer Söller, ${ }^{1}$ Peter Hirsch, ${ }^{2}$ Dietmar Blohm ${ }^{1}$ and Matthias Labrenz ${ }^{2}$
}

Author for correspondence: Matthias Labrenz. Tel: +49431880 4344. Fax: +494318802194. e-mail: mlabrenz@ifam.uni-kiel.de

1 Universität Bremen, FB2UFT, Abt. Biotechnologie \& Mol. Genetik, Leobener Str., D-28359 Bremen, Germany

2 Institut für Allgemeine Mikrobiologie, Am Botanischen Garten 1-9, D-24118 Kiel, Germany
The 16S-23S rDNA internal transcribed spacer (ITS) of Roseobacter denitrificans, Roseobacter litoralis, Ruegeria algicola and strains of the recently described species Antarctobacter heliothermus and Roseovarius tolerans were analysed in order to examine DNA sequence variations and to draw conclusions about inter- and intraspecific relationships. A. heliothermus included four strains with an ITS fragment length of $1092 \mathrm{bp}$. Roseovarius tolerans was described on the basis of eight strains. Five of these harboured two ITS fragments of different lengths (959 and about $1100 \mathrm{bp}$ ), while the others had one fragment of either 1083 bp (two strains) or 1165 bp (one strain). ITS lengths of the related species Roseobacter denitrificans, Roseobacter litoralis and Ruegeria algicola were found to be 980, 984 and 1158 bp, respectively. Phylogenetic analyses of the DNA sequences allowed species affiliation of strains with sequence length differences of $>200$ bp and recognition of relationships based on a well-supported ITS tree. The strains of A. heliothermus and Roseovarius tolerans each formed a monophyletic branch and they were separated from each other by Ruegeria algicola. This species was now clearly separated from Roseobacter denitrificans and Roseobacter litoralis, which corresponded to the new genus affiliation of Ruegeria algicola. These data were additionally supported by analyses of the structure, relative position and order of genes for tRNA $A_{l \mathrm{le}}$ and TRNA $_{\mathrm{Ala}}$ found within the ITS of each strain. Comparative DNA sequence analyses of ITS and 16S rDNA revealed limitations, on species and strain levels, with respect to the phylogenetic resolution of the 16S rDNA due to the limited number of informative (variable) sites, while ITS sequence analyses provided more variable and sufficiently conserved positions to discriminate between strains and to reconstruct their taxonomic relationships.

Keywords: Roseobacter, Roseovarius, Antarctobacter, Ruegeria, 16S-23S rDNA ITS

\section{INTRODUCTION}

Length and sequence polymorphisms found in the 16S-23S rDNA internal transcribed spacer (ITS) have been used for the discrimination of bacterial species (Barry et al., 1991; Gürtler \& Stanisich, 1996; Lu et al., 1997). Even strains of one species have been differen-

Abbreviations: ASW, artificial sea water; ITS, internal transcribed spacer; MP, maximum parsimony; NJ, neighbour joining.

The EMBL accession numbers for the 16S-23S ITS sequences reported in this paper are AJ012700-AJ012707. tiated (Hain et al., 1997; Vinuesa et al., 1998). The construction of specific primer pairs for the whole or parts of the rDNA spacer region has made it possible to identify species or genera by the length of PCR products (Forsman et al., 1997; Gu et al., 1998). This tool for fast species identification is of growing interest, especially for fast detection of pathogenic microorganisms. However, the discrimination of strains has often proved impossible when ITS lengths alone were compared (Centurion-Lara et al., 1996; Mendoza et al., 1998), although inter-strain discrimination was successful with Legionella spp. when PCR-RFLP 
analysis of ITS sequences was applied (Riffard et al., 1998). Resolution of species and strains was achieved more precisely with DNA sequence analyses of the ITS (Leblond-Bourget et al., 1996; Yoon et al., 1997, 1998; Roth et al., 1998). In comparison with a discrimination of strains by PCR-RFLP, an alignment of orthologous ITS sequences yields the exact length of PCR products and would also allow the estimation of pairwise evolutionary distances, the resolution of interstrain relationships and the fine-tuning of phylogenetic trees derived from $16 \mathrm{~S}$ rDNA.

Antarctobacter heliothermus (Labrenz et al., 1998) was recently described on the basis of four strains with nearly identical morphological and physiological characteristics, while Roseovarius tolerans (Labrenz et al., 1999) comprised eight strains with different colony colours, variable bacteriochlorophyll $a$ content and other minor phenotypic heterogeneities. However, $16 \mathrm{~S}$ rDNA sequence analysis, DNA-DNA hybridizations and very homogeneous chemotaxonomic data suggested the affiliation of all eight strains of Roseovarius with one species (Labrenz et al., 1999).

This study was aimed at the differentiation of strains of the genera and species of $A$. heliothermus, Roseovarius tolerans and other closely related representatives of the Roseobacter group belonging to the $\alpha$-Proteobacteria. In order to gain additional support for the affiliation of strains of both new genera, their $16 \mathrm{~S}-23 \mathrm{~S}$ ribosomal ITS was analysed for length of PCR products, DNA sequence variability and structural features of tRNA genes. Also, their relationships to Ruegeria algicola (Uchino et al., 1998), originally described as Roseobacter algicola (Lafay et al., 1995), Roseobacter litoralis and Roseobacter denitrificans needed to be clarified with these methods. The ITS-derived affiliation was furthermore compared with the phylogenetic relationships reconstructed from the $16 \mathrm{~S}$ rDNA sequence comparison.

\section{METHODS}

Bacterial strains and culture conditions. The following cultures were used: Roseobacter denitrificans (DSM 7001 ${ }^{\mathrm{T}}$ ), Roseobacter litoralis (DSM 6996 ${ }^{\mathrm{T}}$ ), Ruegeria algicola (DSM $\left.10251^{\mathrm{T}}\right)$, Antarctobacter heliothermus strains EL-219 ${ }^{\mathrm{T}}$ (=DSM 11445 $)$, EL-165 (=DSM 11440), EL-54 and EL185 and Roseovarius tolerans strains EL-172 ${ }^{\mathrm{T}}$ (=DSM $11457^{\mathrm{T}}$ ), EL-222 ( = DSM 11463), EL-52, EL-78, EL-83, EL90, EL-164 and EL-171. All strains were cultivated at $20^{\circ} \mathrm{C}$ in oligotrophic medium PYGV prepared with $25 \%$ artificial sea water (or with $40 \%$ artificial sea water for EL-83 and EL-54) as described previously (Labrenz et al., 1998, 1999).

DNA extraction. Wet cells (200 mg) were suspended in $1 \mathrm{ml}$ saline EDTA (150 mM NaCl, $100 \mathrm{mM}$ EDTA, pH 8) and centrifuged and the pellet was resuspended in $1 \mathrm{ml}$ proteinase $\mathrm{K}$ buffer (0.01 M Tris/HCl, 0.005 M EDTA, 0.50\% SDS, $\mathrm{pH} 7 \cdot 8)$. Cell lysis and DNA extraction were achieved by adding $15 \mu \mathrm{l}$ proteinase $\mathrm{K}\left(20 \mathrm{mg} \mathrm{ml}^{-1}\right)$ and $5.5 \mu 122.7 \%$ $(\mathrm{w} / \mathrm{v}) \mathrm{SDS}$ and incubating at $55^{\circ} \mathrm{C}$ for $1 \mathrm{~h}$. Next, $55 \mu \mathrm{l}$ $22.7 \%$ SDS and $40 \mu 15 \mathrm{M} \mathrm{NaCl}$ were added, followed by phenol extraction and ethanol precipitation.
PCR amplification and direct DNA sequencing of the 16S-23S rDNA ITS. Amplification of the ITS was performed according to Scheinert et al. (1996) in a reaction volume of $50 \mu \mathrm{l}$, which contained 150-250 ng genomic DNA, $50 \mathrm{pmol}$ each of primers 5'-AAGTCGTAACAAGGTARC-3' (region 3 on the basis of the criteria given by Gürtler \& Stanisich, 1996; positions $1492-1509$ of $16 \mathrm{~S}$ rDNA) and 5'GGTTBCCCCATTCRG-3' (region 6; Gürtler \& Stanisich, 1996;positions 115-130 of 23S rDNA), $0 \cdot 2 \mathrm{mM}$ each of dATP, dCTP, dGTP and dTTP (Boehringer Mannheim), 1 $\mathrm{U}$ Taq polymerase (Appligene) and the recommended PCR buffer $(10 \times$ concentrated, Appligene). The reaction mixture was covered with $40 \mu \mathrm{l}$ Chill out wax (MJ Research). Nucleotide positions for the primers are according to the Escherichia coli numbering for the respective ribosomal genes of the $r r n B$ operon (Brosius et al., 1981), and primers were manufactured by Pharmacia.

Thermal cycling (Mastercycler 5330; Eppendorf) was started hot (heated to $94{ }^{\circ} \mathrm{C}$, cooled to $82^{\circ} \mathrm{C}$ after $5 \mathrm{~min}$, held until polymerase addition), followed by 24 cycles of $94^{\circ} \mathrm{C}$ denaturation $(30 \mathrm{~s}), 48^{\circ} \mathrm{C}$ annealing $(30 \mathrm{~s})$ and $72{ }^{\circ} \mathrm{C}$ elongation $(20 \mathrm{~s})$. The final $72^{\circ} \mathrm{C}$ elongation step was prolonged for $7 \mathrm{~min}$ and terminated by cooling to $4^{\circ} \mathrm{C}$. PCR products were analysed with a $0.8 \%(\mathrm{w} / \mathrm{v})$ agarose gel (analytical grade, Promega) in TBE buffer (Sambrook et al., 1989). PCR products were excised from the agarose gel and recovered using the QiaEx kit (Qiagen) according to the manufacturer's instructions, except that, for improved recovery, DNA was eluted twice at $50{ }^{\circ} \mathrm{C}$ with $40 \mu 11 \mathrm{mM}$ Tris $/ \mathrm{HCl}, \mathrm{pH} 8 \cdot 0$. In order to allow rapid strain discrimination, only the shortest PCR product was prepared in those cases where two PCR bands were amplified, as with strain EL-172 ${ }^{\mathrm{T}}$. The amount of eluted DNA was estimated visually after running $1 / 10$ of the recovered volume on a $1 \%(\mathrm{w} / \mathrm{v})$ agarose gel and comparing band intensities to a DNA mass ladder (Gibco-BRL).

DNA sequence analyses. DNA sequencing reactions were set up using the PRISM Ready Reaction dye deoxy terminator AmpliTaq FS kit (PE-Applied Biosystems) for direct PCR fragment sequencing according to the manufacturer's recommendations, except that the total reaction volume was reduced to $10 \mu \mathrm{l}$, which contained the eluted DNA (200 ng), the sequencing primer $(2.5 \mathrm{pmol}$; one of the PCR primers or a specific internal primer) and $2 \mu$ of the Ready Reaction mix including AmpliTaq FS polymerase. Cycle sequencing was done on a Trio-Block thermal cycler (Biometra) with 25 cycles of $96^{\circ} \mathrm{C}$ for $15 \mathrm{~s}, 50{ }^{\circ} \mathrm{C}$ for $15 \mathrm{~s}$ (but varying between 45 and $60^{\circ} \mathrm{C}$, depending on the primer melting points) and $60{ }^{\circ} \mathrm{C}$ for $4 \mathrm{~min}$. Excess dye terminators were removed by ethanol precipitation. Electrophoretic separation and online analysis of the sequence reactions were performed on an ABI 377 automated sequencer running a $5 \%(\mathrm{w} / \mathrm{v})$ polyacrylamide gel (Long Ranger; FMC BioProducts).

The use of both PCR primers as sequencing primers resulted in single-stranded sequences of at least $700 \mathrm{bp}$ reading length. The following walking primers were designed to obtain complete double-stranded DNA sequences: (i) forward primer $\left(5^{\prime}-3^{\prime}\right)$, A. heliothermus CATAAGTGTTTGGCAATCTCG, Roseovarius tolerans and Roseobacter species including Ruegeria algicola GATTTGCATTCAGGAGGTCA; (ii) reverse primer $\left(5^{\prime}-3^{\prime}\right), A$. heliothermus GCCTTGCAGCGATCCTTTAT, Roseovarius tolerans TATCTCTCTAWACGATGTCAA and Roseobacter species including Ruegeria algicola GTTAGTGTACTTGACTTGGAC. DNA sequences were inspected visually using 
the program SEQUENCE NAVIGATOR (PE-Applied Biosystems), ensuring reliable sequence data. DNA sequences were deposited in the EMBL database (for accession numbers see Table 1).

tRNA genes. Scanning for tRNA genes in ITS sequences was done with the program tRNASCAN-SE (version 1.11; Lowe \& Eddy, 1997), which provided cloverleaf structures of the sequences identified. Phylogenetic analysis of tRNA features was done using common cladistic rules for traditional character analyses (Hennig, 1966).

Sequence alignment and phylogenetic analyses. The fulllength ITS sequences were pre-aligned using the CLUSTAL option of the program MEGALIGN (Lasergene; DNASTAR) and checked by eye. Sequence statistics and phylogenetic analyses were performed using the program PAUP (test version 4.0d64, with the author's permission; Swofford, 1998) and checked in MEGA (version 1.01; Kumar et al., 1993). Trees were computed either in both programs [neighbour-joining (NJ) trees; Saitou \& Nei, 1987] or in PAUP only [maximum parsimony (MP) trees]. The alignment of ITS sequences is available by anonymous FTP from the EMBL FTP server (ftp://ftp.ebi.ac.uk/pub/databases/ embl/align/) under accession number ds 36433 .

The 16S rRNA gene sequences used for phylogenetic tree construction (Fig. 2b) were received as a sub-alignment from the universal SSU alignment of the ribosomal database (RDP database, Maidak et al., 1997), omitting common gaps. Sequences not included in the RDP database were added manually. The final alignment of both ITS and 16S rDNA sequences included the following taxa (accession numbers in parentheses): A. heliothermus EL-219 ${ }^{\mathrm{T}}$ (Y11552), Roseovarius tolerans EL-172 ${ }^{\mathrm{T}}$ (Y11551), Ruegeria algicola ATCC 51440 ${ }^{\mathrm{T}}$ (X78315), Roseobacter denitrificans ATCC $33942^{\mathrm{T}}$ (M96746) and Roseobacter litoralis ATCC $49566^{\mathrm{T}}$ (X78312).

\section{RESULTS}

Approximations of ITS lengths were obtained from an agarose gel (Fig. 1). Strain EL-219 ${ }^{\mathrm{T}}$ ( $1100 \mathrm{bp}$ ) represented the $A$. heliothermus strains with equal ITS

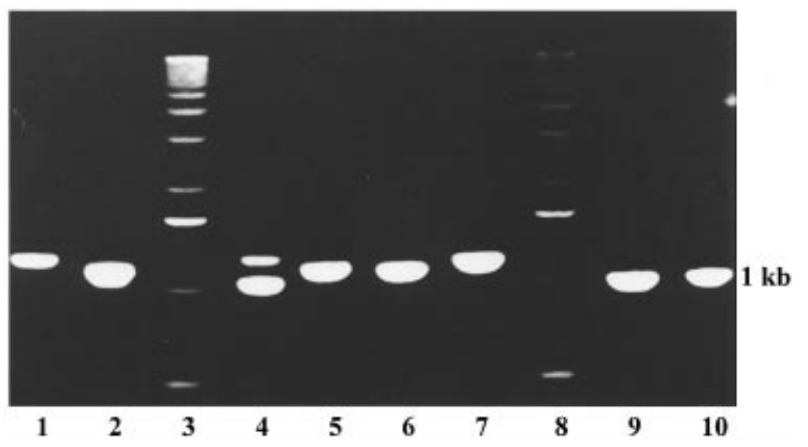

Fig. 1. Ethidium bromide-stained agarose gel displaying length variations of 16S-23S rDNA ITS PCR fragments. Lanes: 1, Roseovarius tolerans EL-164 ( $1200 \mathrm{bp}) ; 2$, Roseovarius tolerans EL-171 ( $1100 \mathrm{bp})$; 3, $1 \mathrm{~kb}$ ladder; 4, Roseovarius tolerans EL-172 ${ }^{\top}$ ( 1000 bp plus $\left.\sim 1200 \mathrm{bp}\right) ; 5$, A. heliothermus EL-219 ${ }^{\top}$ ( $\left.1100 \mathrm{bp}\right) ; 6$, Roseovarius tolerans EL-222 ( $\left.1100 \mathrm{bp}\right)$; 7, Ruegeria algicola DSM 10218 ${ }^{\top}(\sim 1200 \mathrm{bp}) ; 8,1 \mathrm{~kb}$ ladder; 9, Roseobacter litoralis DSM $6996^{\top}(\sim 1000 \mathrm{bp})$; and 10, Roseobacter denitrificans DSM $7001^{\top}(\sim 1000 \mathrm{bp})$. lengths. EL-172 17 and four strains of Roseovarius tolerans (EL-52, EL-78, EL-83 and EL-90) had two ITS fragments of different lengths $(\sim 1000 \mathrm{bp}$ and $\sim 1200 \mathrm{bp}$ ), whereas three other Roseovarius tolerans strains had one ITS of either $\sim 1100$ bp (EL-171, EL222) or $\sim 1200$ bp (EL-164). The ITS of Ruegeria algicola $(\sim 1200 \mathrm{bp})$, Roseobacter litoralis $(\sim 1000 \mathrm{bp})$ and Roseobacter denitrificans ( $1000 \mathrm{bp})$ showed lengths similar to those of the two ITS bands of Roseovarius tolerans. Thus, a clear species or strain differentiation could not be obtained in this way. More accurate and discriminating ITS lengths were obtained from DNA sequencing (Table 1), including approximately $150 \mathrm{bp}$ of the $16 \mathrm{~S}$ and $23 \mathrm{~S}$ rDNA, which revealed only a few differences in nucleotide sequences. Strains EL-171 and EL-222 of Roseovarius tolerans were identical with respect to both ITS length and DNA sequence and hence represented one branch in the phylogenetic tree (Fig. 2a).

A search for tRNAs within the ITS resulted in a set of two tRNA genes found in each strain, $\mathrm{tRNA}_{\mathrm{Ala}}$ and tRNA $_{\text {Ile }}$. The tRNA Ile consisted of $77 \mathrm{bp}$ (identical in all strains) and the $\mathrm{tRNA}_{\mathrm{Ala}}$ was $76 \mathrm{bp}$. According to tRNA consensus structure numbering, the length difference between the tRNAs was caused by an additional $U$ in a variable position (20a) of the tRNA $\mathrm{D}$ loop. Structural differences and the relative positions and order of tRNA genes identified are shown in Table 1. Sequence differences in the conserved base-paired positions 51/63 and 52/62 in the tRNA $_{\text {Ala }}$ T $\Psi C$ stem allowed the differentiation of two groups: (i) Roseobacter denitrificans and Roseobacter litoralis and (ii) Roseovarius tolerans, Ruegeria algicola and $A$. heliothermus. The latter species was separated from the other two species as a single line of descent by an inverse order of the tRNA genes (Table 1). Strains of Roseovarius tolerans and Ruegeria algicola contained the same set of tRNA genes with respect to structure and order, but in different relative locations with respect to flanking rRNA genes. Considering the tRNA genes only, further discrimination of the Roseovarius tolerans strains was not possible (Table 1). All tRNA features described supported individual branches of the ITS tree derived from the phylogenetic analyses of total ITS sequences (Fig. 2a).

The overall presence of a phylogenetic signal within the ITS sequences was demonstrated by a left-skewed distribution (data not shown) of $10^{6}$ randomly sampled trees (parsimony analyses), according to Hillis \& Huelsenbeck (1992). Data sets containing phylogenetic signals result in a significantly left-skewed distribution, while those containing random noise result in symmetrical distributions. The g1 statistic is a measure of the skewness of a distribution and critical values of $\mathrm{gl}$ for tree length distributions of data sets containing different taxa, sequence lengths and variabilities are given by Hillis \& Huelsenbeck (1992). The calculated value for $\mathrm{g} 1$ of -1.40 is considerably less than the $95 \%$ and even the $99 \%$ critical value (between -0.39 and 
Table 1. Features of 16S-23S rDNA ITS sequences

Sequences include 32 nucleotides from the $3^{\prime}$ end of the $16 \mathrm{~S}$ rDNA and approximately 120 nucleotides from the $5^{\prime}$ end of the $23 \mathrm{~S}$ rDNA.

\begin{tabular}{|c|c|c|c|c|c|c|}
\hline Species & Strain & Length (nt) & $\begin{array}{c}\text { tDNA }_{\text {Ile }} \\
\text { location (nt) }\end{array}$ & $\begin{array}{l}\text { tDNA }_{\mathrm{Ala}} \\
\text { location (nt) }\end{array}$ & $\begin{array}{c}\text { Base substitution in the } \mathrm{T} \psi \mathrm{C} \\
\operatorname{arm} \text { of } \mathrm{tRNA_{Ala }}{ }^{*}\end{array}$ & $\begin{array}{c}\text { Accession } \\
\text { number }\end{array}$ \\
\hline \multirow[t]{4}{*}{ Roseovarius tolerans } & EL-164 & 1165 & $207-283$ & $425-500$ & $\begin{array}{l}\text { AGGAGUUCGAUCCUCCU } \ddagger \\
>>>>\ldots \ldots<<<\end{array}$ & AJ012701 \\
\hline & EL-171 & 1083 & $207-283$ & $425-500$ & & AJ012702 \\
\hline & $\mathrm{EL}-172^{\mathrm{T}} \dagger$ & 959 & $170-246$ & $346-421$ & & AJ012700 \\
\hline & EL-222 & 1083 & $207-283$ & $425-500$ & & AJ012703 \\
\hline Ruegeria algicola & $\operatorname{DSM} 10251^{\mathrm{T}}$ & 1158 & $239-315$ & $492-567$ & $\begin{array}{l}\text { AGGAGUUCGAUCCUCCU } \\
>>>>\ldots \ldots<<<\end{array}$ & AJ012705 \\
\hline A. heliothermus & EL-219 & 1092 & $350-426$ & $250-325$ & $\begin{array}{l}\text { AGGAGUUCGAUCCUCCU } \\
>>>>\ldots \ldots<<<\end{array}$ & AJ012704 \\
\hline Roseobacter denitrificans & $\operatorname{DSM} 7001^{\mathrm{T}}$ & 980 & $243-319$ & $338-413$ & $\begin{array}{l}\text { AGCGGUUCGAUCCCGCU } \\
>>>>\ldots \ldots<<<<\end{array}$ & AJ012706 \\
\hline Roseobacter litoralis & DSM $6996^{\mathrm{T}}$ & 984 & $243-319$ & $338-413$ & $\begin{array}{l}\text { AGCGGUUCGAUCCCGCU } \\
>>>>\ldots \ldots<<<<\end{array}$ & AJ012707 \\
\hline
\end{tabular}

* Base positions 49-65 according to tRNA consensus numbering; $>>,<<$ and dots indicate bases involved in stem-loop structures. $\dagger$ ITS sequence from lower band (Fig. 1).

+ Identical in all Roseovarius tolerans strains.
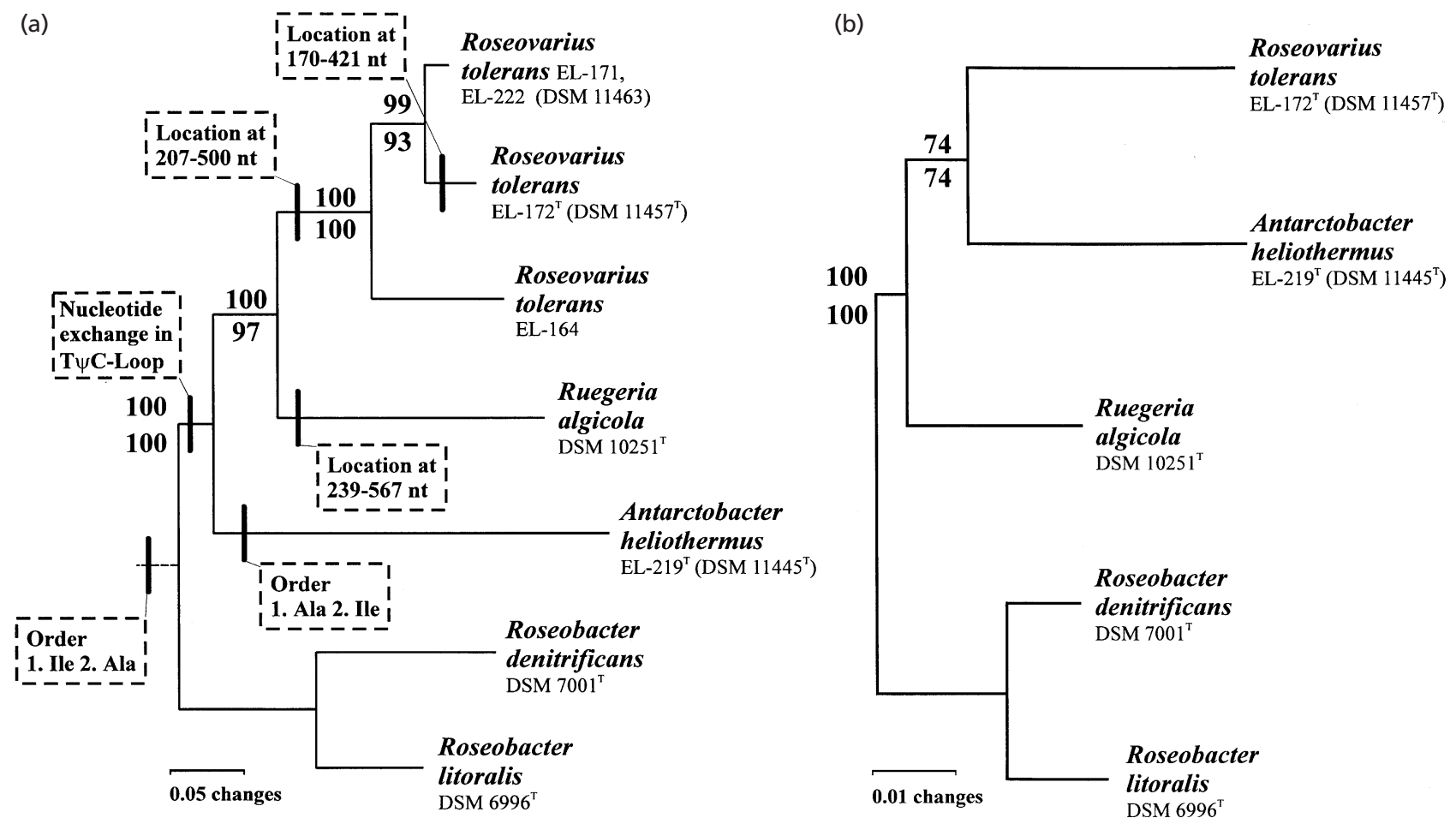

Fig. 2. Phylogenetic trees reconstructed from ITS (a) and 16S rDNA (b) sequence alignments (1279 and 1278 positions, respectively) using PAUP. Rooting was done using the sequences of Roseobacter litoralis and Roseobacter denitrificans as a monophyletic outgroup. Bootstrap values (\%) obtained from resampling of 1000 replications are indicated above (NJ) and below (MP) branches. NJ trees were calculated using pairwise distances (Table 2); the scale bar indicates base changes. MP trees were based on 390 (ITS) or 60 (16S rDNA) parsimony-informative positions (Branch and Bound search, unweighted). MPT step-length (ITS/16S rDNA) $=1329 / 187$, consistency index $=0 \cdot 877 / 0 \cdot 888$. 'Heuristic search' was applied for computation of bootstrap values. Additional support of individual branches (ITS tree only) by tRNA characters is indicated. 
Table 2. Pairwise computed distances between ITS and $16 \mathrm{~S}$ rRNA gene sequences

Values shown are the percentages of nucleotide positions where the two sequences differ. The sequences compared are those of the ITS (below the diagonal) and 16S rRNA genes (above the diagonal). ND, Not determined.

\begin{tabular}{|lccccccc|}
\hline Taxon & $\mathbf{1}$ & $\mathbf{2}$ & $\mathbf{3}$ & $\mathbf{4}$ & $\mathbf{5}$ & $\mathbf{6}$ & $\mathbf{7}$ \\
\hline 1. Roseovarius tolerans EL-171, EL-222 & - & $0^{*}$ & $0^{*}$ & $\mathrm{ND}$ & $\mathrm{ND}$ & $\mathrm{ND}$ & $\mathrm{ND}$ \\
2. Roseovarius tolerans EL-172 & $5 \cdot 10$ & - & $0^{*}$ & $5 \cdot 51$ & $6 \cdot 50$ & $7 \cdot 30$ & $7 \cdot 33$ \\
3. Roseovarius tolerans EL-164 & $12 \cdot 26$ & $17 \cdot 86$ & - & $\mathrm{ND}$ & $\mathrm{ND}$ & $\mathrm{ND}$ & $\mathrm{ND}$ \\
4. Ruegeria algicola DSM 10251 & $32 \cdot 33$ & $28 \cdot 46$ & $33 \cdot 64$ & - & $6 \cdot 54$ & $5 \cdot 23$ & $4 \cdot 79$ \\
5. A. heliothermus EL-219 & $43 \cdot 22$ & $43 \cdot 78$ & $46 \cdot 75$ & $48 \cdot 12$ & - & $6 \cdot 81$ & $6 \cdot 28$ \\
6. Roseobacter denitrificans DSM 7001 & $40 \cdot 91$ & $40 \cdot 98$ & $41 \cdot 62$ & $47 \cdot 79$ & $48 \cdot 94$ & - & $2 \cdot 09$ \\
7. Roseobacter litoralis DSM $6996^{\mathrm{T}}$ & $36 \cdot 24$ & $35 \cdot 32$ & $37 \cdot 47$ & $40 \cdot 11$ & $46 \cdot 50$ & $19 \cdot 24$ & - \\
\hline
\end{tabular}

* The 16S rRNA genes of Roseovarius tolerans non-type strains were partially sequenced (approx. $800 \mathrm{bp}$ ) and revealed $100 \%$ identity to Roseovarius tolerans EL-172 ${ }^{\mathrm{T}}$ (Labrenz et al., 1999).

-0.49 for seven taxa and 250-500 parsimonyinformative characters). This suggests that the ITS sequence alignment contains a significant phylogenetic signal.

Genetic distances of both ITS and 16S rDNA sequences are shown in Table 2. Pairwise computed distances of ITS sequences were approximately 5- to 9fold larger than 16S rDNA distances. Phylogenetic trees reconstructed from ITS sequences using the neighbour-joining (NJ) or maximum-parsimony (MP) methods are shown in Fig. 2(a). The two tree reconstruction methods resulted in trees of identical topologies and were supported by high bootstrap values. Individual branches of the trees were additionally supported by the results of the comparative structural analysis and relative gene positions of tRNAs within the ITS (Table 1), as indicated on the phylogenetic tree (Fig. 2a). The fact that the two tree reconstruction methods produced identical trees indicated that the phylogenetic relationships presented here were probably not affected by the program algorithms applied. The species, as well as most strains, were clearly separated and strains of a species clustered together. All strains of Roseovarius tolerans formed a monophyletic branch separated from $A$. heliothermus EL-219 ${ }^{\mathrm{T}}$ by Ruegeria algicola. However, this did not agree with the tree reconstructed from 16S rDNA sequences (Fig. 2b).

Again, the two phylogenetic trees reconstructed from $16 \mathrm{~S}$ rDNA sequences using the NJ and MP algorithms showed consistent topologies (Fig. 2b), contradicting the close relationship of Ruegeria algicola and Roseovarius tolerans suggested by the ITS tree. Instead, Roseovarius tolerans and $A$. heliothermus appeared as sibling species, but less well supported by bootstrapping than the ITS tree.

\section{DISCUSSION}

ITS length differences of about $200 \mathrm{bp}$ were detected between EL-164 and the lower band of Roseovarius tolerans EL-172 ${ }^{\mathrm{T}}$. Species- and even strain-level relationships were consistently resolved in a phylogenetic analysis of the ITS sequences independently of the method of tree construction (NJ or MP). The positions of individual branches were strongly supported by bootstrap values and by structural peculiarities of tRNA genes. Differences found between strains of Roseovarius tolerans in the relative position of tRNAs corresponded to phenotypic heterogeneities. Previous studies have revealed strong resemblances between the strains with respect to chemotaxonomical, biochemical and physiological data (Labrenz et al., 1999), but also a few minor heterogeneities. However, no further correlations between ITS sequence data and phenotypic heterogeneities could be found.

Compared with the position and clustering of the genera Antarctobacter and Roseovarius in the $16 \mathrm{~S}$ rDNA tree of Labrenz et al. (1998) and a corresponding sub-tree including only the strains of this present study (Fig. 2b), a better-supported resolution of relationships based on ITS sequences is shown in Fig. 2(a). In contrast, phylogenetic trees obtained from the 16S rRNA alignment were less well supported by bootstrap values (Fig. 2b), especially if one considers relationships within the cluster formed by Ruegeria algicola, Roseovarius and Antarctobacter. A questionable reliability was already apparent from the clearly poor $\mathrm{g} 1$ value $(\mathrm{g} 1=-0.622)$. While critical values for five taxa and 60 parsimony-informative characters range between -0.78 and -0.93 (Hillis \& Huelsenbeck, 1992), g1 values from data that are significantly more structured than random should be more negative. This was probably due to the strikingly smaller sequence distances compared with the ITS sequences (Table 2). Greater distances would be needed for reliable resolution of interspecific and interstrain relationships in phylogenetic reconstructions. Consequently, the strongly supported relationship of Roseovarius and Ruegeria algicola in the ITS tree (Fig. $2 \mathrm{a}$, bootstrap values 100 or $97 \%$ ) was more probable 
than the less well supported relationship of Roseovarius and Antarctobacter in the 16S rDNA tree (Fig. 2b, bootstrap value $74 \%$ ). This conclusion was additionally supported by the inverse order of tRNA genes in the ITS of $A$. heliothermus (Fig. 2b), separating it from Ruegeria algicola and Roseovarius tolerans. The separation of Ruegeria algicola from the outgroup Roseobacter denitrificans and Roseobacter litoralis was strongly supported by sequence differences in the

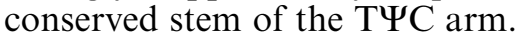

Thus, although the ITS and 16S rDNA trees do not agree concerning the phylogenetic relationships of Ruegeria algicola, the ITS tree presented here is in good agreement with the 16S rDNA tree of Labrenz et al. (1998), which included more species. Similarly, the addition of more ITS sequences from isolates in the phylogenetic vicinity of Ruegeria algicola would lead to a more profound view. The use of further chemotaxonomic data is recommended in order to gain additional support.

Generally, the presence of multiple rDNA operons in certain species (Hain et al., 1997) may cause problems in a rapid ITS analysis when PCR fragments are sequenced directly. In these cases, a preparation of only the smallest ITS band would give enough information for well-supported phylogenetic relationships, as was shown with Roseovarius tolerans $\mathrm{EL}-172^{\mathrm{T}}$ (Fig. 2a). However, the analysis of multiple ITS sequences of one strain could complicate resolution of inter-strain relationships, as was reported for two Bacillus subtilis strains (Nagpal et al., 1998).

In conclusion, the application of rapid, direct ITS sequence analyses and reconstruction of phylogenetic relationships (which were reported here for a particular group of the $\alpha$-Proteobacteria) has become increasingly important when focusing on the species level of biodiversity. Small subunit rDNA analyses (prokaryotes and eukaryotes) or mitochondrial sequence analysis (eukaryotes) would not cope with the demand for the phylogenetic resolution that is needed to describe the notable inter- and intraspecific biodiversity that is expected (Pace, 1997; Stork, 1997).

\section{ACKNOWLEDGEMENTS}

This work was supported by grants from the Deutsche Forschungsgemeinschaft to P.H. (Hi 68/25-1 to -3).

\section{REFERENCES}

Barry, T., Colleran, G., Glennon, M., Dunican, L. K. \& Gannon, F. (1991). The $16 \mathrm{~S} / 23 \mathrm{~S}$ ribosomal spacer region as a target for DNA probes to identify eubacteria. PCR Methods Appl 1, 51-56.

Brosius, J., Dull, T. J., Sleeter, D. D. \& Noller, H. F. (1981). Gene organization and primary structure of a ribosomal RNA operon from Escherichia coli. J Mol Biol 148, 107-127.

Centurion-Lara, A., Castro, C., van Voorhis, W. C. \& Lukehart, S. A. (1996). Two $16 \mathrm{~S}-23 \mathrm{~S}$ ribosomal DNA intergenic regions in different Treponema pallidum subspecies contain $t R N A$ genes. FEMS Microbiol Lett 143, 235-240.
Forsman, P., Tilsala-Timisjärvi, A. \& Alatossava, T. (1997). Identification of staphylococcal and streptococcal causes of bovine mastitis using $16 \mathrm{~S}-23 \mathrm{~S}$ rRNA spacer regions. Microbiology 143, 3491-3500.

Gu, X. X., Rossau, R., Jannes, G., Ballard, R., Laga, M. \& Van Dyck, E. (1998). The rrs (16S)-rrl (23S) ribosomal intergenic spacer region as a target for the detection of Haemophilus ducreyi by a heminested-PCR assay. Microbiology 144, 1013-1019.

Gürtler, V. \& Stanisich, V. A. (1996). New approaches to typing and identification of bacteria using the $16 \mathrm{~S}-23 \mathrm{~S}$ rDNA spacer region. Microbiology 142, 3-16.

Hain, T., Ward-Rainey, N., Kroppenstedt, R. M., Stackebrandt, E. \& Rainey, F. A. (1997). Discrimination of Streptomyces albidoflavus strains based on the size and number of $16 \mathrm{~S}-23 \mathrm{~S}$ ribosomal DNA intergenic spacers. Int J Syst Bacteriol 47, 202-206.

Hennig, w. (1966). Phylogenetic Systematics. Urbana, IL: University of Illinois Press.

Hillis, D. M. \& Huelsenbeck, J. P. (1992). Signal, noise, and reliability in molecular phylogenetic analyses. $J$ Hered $\mathbf{8 3}$, 189-195.

Kumar, S., Tamura, K. \& Nei, M. (1993). MEGA: Molecular evolutionary genetics analyses, version 1.01. Pennsylvania State University, University Park, PA, USA.

Labrenz, M., Collins, M. D., Lawson, P. A., Tindall, B. J., Braker, G. \& Hirsch, P. (1998). Antarctobacter heliothermus gen. nov., sp. nov., a budding bacterium from hypersaline and heliothermal Ekho Lake. Int J Syst Bacteriol 48, 1363-1372.

Labrenz, M., Collins, M. D., Lawson, P. A., Tindall, B. J., Schumann, P. \& Hirsch, P. (1999). Roseovarius tolerans gen. nov., sp. nov., a budding bacterium with variable bacteriochlorophyll $a$ production from hypersaline Ekho Lake. Int J Syst Bacteriol 49, 137-147.

Lafay, B., Ruimy, R., Rausch de Traubenberg, C., Breittmayer, V., Gauthier, M. J. \& Christen, R. (1995). Roseobacter algicola sp. nov., a new marine bacterium isolated from the phycosphere of the toxin-producing dinoflagellate Prorocentrum lima. Int J Syst Bacteriol 45, 290-296.

Leblond-Bourget, N., Philippe, H., Mangin, I. \& Decaris, B. (1996). $16 \mathrm{~S}$ rRNA and $16 \mathrm{~S}$ to $23 \mathrm{~S}$ internal transcribed spacer sequence analyses reveal inter- and intraspecific Bifidobacterium phylogeny. Int J Syst Bacteriol 46, 102-111.

Lowe, T. M. \& Eddy, S. R. (1997). tRNAscan-SE: a program for improved detection of transfer RNA genes in genomic sequence. Nucleic Acids Res 25, 955-964.

Lu, W., Evans, E. H., McColl, S. M. \& Saunders, V. A. (1997). Identification of cyanobacteria by polymorphisms of PCRamplified ribosomal DNA spacer region. FEMS Microbiol Lett 153, 141-149.

Maidak, B. L., Olsen, G. J., Larsen, N., Overbeek, R., McCaughey, M. J. \& Woese, C. R. (1997). The RDP (Ribosomal Database Project). Nucleic Acids Res 25, 109-111.

Mendoza, M., Meugnier, H., Bes, M., Etienne, J. \& Freney, J. (1998). Identification of the Staphylococcus species by $16 \mathrm{~S}-23 \mathrm{~S}$ rDNA intergenic spacer PCR analysis. Int J Syst Bacteriol 48, 1049-1055.

Nagpal, M. L., Fox, K. F. \& Fox, A. (1998). Utility of 16S-23S rRNA spacer region methodology: how similar are interspace regions within a genome and between strains for closely related organisms? J Microbiol Methods 33, 211-219. 
Pace, N. R. (1997). A molecular view of microbial diversity and the biosphere. Science 276, 734-740.

Riffard, S., Lo Presti, F., Normand, P., Forey, F., Reyrolle, M., Etienne, J. \& Vandenesch, F. (1998). Species identification of Legionella via intergenic 16S-23S ribosomal spacer PCR analysis. Int J Syst Bacteriol 48, 723-730.

Roth, A., Fischer, M., Hamid, M. E., Michalke, S., Ludwig, W. \& Mauch, H. (1998). Differentiation of phylogenetically related slowly growing mycobacteria based on 16S-23S rRNA gene internal transcribed spacer sequences. J Clin Microbiol 36, 139-147.

Saitou, N. \& Nei, M. (1987). The neighbor-joining method: a new method for reconstructing phylogenetic trees. Mol Biol Evol 4, 406-425.

Sambrook, J., Fritsch, E. F. \& Maniatis, T. (1989). Molecular Cloning : a Laboratory Manual, 2nd edn. Cold Spring Harbor, NY : Cold Spring Harbor Laboratory.

Scheinert, P., Krausse, R., Ullmann, U., Söller, R. \& Krupp, G. (1996). Molecular differentiation of bacteria by PCR amplification of the 16S-23S rRNA spacer. J Microbiol Methods 26, 103-117.

Stork, N. E. (1997). Measuring global biodiversity and its decline. In Biodiversity II, chapter 5, pp. 41-68. Edited by M. L. ReakeKudla, D. E. Wilson \& E. O. Wilson. Washington, DC: Joseph Henry Press.

Swofford, D. L. (1998). PAUP: Phylogenetic analysis using par- simony, version 4.0d64. Smithsonian Institute, Washington, DC.

Uchino, Y., Hirata, A., Yokota, A. \& Sugiyama, J. (1998). Reclassification of marine Agrobacterium species: proposals of Stappia stellulata gen. nov., comb. nov., Stappia aggregata sp. nov., nom. rev., Ruegeria atlantica gen. nov., comb. nov., Ruegeria gelatinovora comb. nov., Ruegeria algicola comb. nov., and Ahrensia kieliense gen. nov., sp. nov., nom. rev. J Gen Appl Microbiol 44, 201-210.

Vinuesa, P., Rademaker, J. L. W., de Bruijn, F. J. \& Werner, D. (1998). Genotypic characterization of Bradyrhizobium strains nodulating endemic woody legumes of the Canary Islands by PCR-restriction fragment length polymorphism analysis of genes encoding 16S rRNA (16S rDNA) and 16S-23S rDNA intergenic spacers, repetitive extragenic palindromic PCR genomic fingerprinting, and partial $16 \mathrm{~S}$ rDNA sequencing. Appl Environ Microbiol 64, 2096-2104.

Yoon, J.-H., Lee, S. T., Kim, S.-B., Goodfellow, M. \& Park, Y.-H. (1997). Inter- and intraspecific genetic analysis of the genus Saccharomonospora with $16 \mathrm{~S}$ to $23 \mathrm{~S}$ ribosomal DNA (rDNA) and $23 \mathrm{~S}$ to $5 \mathrm{~S}$ rDNA internally transcribed spacer sequences. Int $J$ Syst Bacteriol 47, 661-669.

Yoon, J.-H., Lee, S. T. \& Park, Y.-H. (1998). Genetic analyses of the genus Nocardioides and related taxa based on 16S-23S rDNA internally transcribed spacer sequences. Int J Syst Bacteriol 48, $641-650$. 